\title{
ORGANIZATIONAL COMMUNICATION: COMMUNICATION AND MOTIVATION IN THE WORKPLACE
}

\author{
Sari Ramadanty ${ }^{1}$; Handy Martinus ${ }^{2}$ \\ ${ }^{1}, 2$ Marketing Communication Department, Bina Nusantara University \\ Jl K.H. Syahdan No. 9, Palmerah \\ 1'sari.ramadanty@gmail.com; ${ }^{2}$ handy_martinus@yahoo.com
}

\begin{abstract}
Every human activity was basically driven by the motivation. Work motivation was a condition or an energy that directed employees to achieve organizational goals of the company. Nowadays, the development of organizational communication saw the communication as one of the most dominant and important activity in the organization and it could be able to motivate employees. The purpose of this study was to reveal how the role of the communication that occurs within the organization could give the motivation to employee. The problem of the research was the relationship employee motivation with factors of communication, such as nonverbal communication, interpersonal communication leadership and communication climate. The method used descriptive qualitative method. Methods of data collection of this study were literature study. Research finds that nonverbal communication, interpersonal communication leadership and communication climate have a significant role to form employee motivation. Nonverbal communication has slightly strong role in shaping the positive motivation to employee. The role includes body communication, facial communication and eye communication. Interpersonal communication leader is based on the satisfaction level of information between management and employees. Management and transparency in openness in downward communication under the form of information from superiors are by listening the communication between supervisors and employees are running smoothly.
\end{abstract}

Keywords: organizational communication, nonverbal communication, interpersonal communication, communication climate, employee motivation

\section{INTRODUCTION}

Nowdays, the development of business is very challenging. To be able to face the challenges and continue to promote corporate profits, all the factors of production, namely, men (human resources), machines and materials must be managed wisely. From of all these factors, human resource is the element that needs special handling. This is because the employee management requires the handling of thinking skill, feeling management, and emotion management to obtain the highest productivity. Organizational communication plays an important role in this challenge. (Rajhans, 2012).

An organization can stand and survive if it has the resources to build a better company. According to G.R. Terry (in Tripathi, 2012), there are basic elements which is a source that can be used (available resources) to achieve the objectives in management. G.R. Terry mentioned tools of management and known as The Six M's in Management, namely, men, money, methods, machines and market.

The success of a company lies in how the company manages the human resources (HR), which is starting from the stage of recruitment, selection, placement, development until the end of the career. Humans become active planners and performers of each organization that can contribute the 
profits for the company. Every company is not just expecting employees who are able, competent, and skilled in their work, but the most important is their eagerness to work hard and achieve optimal result. Therefore, the leaders should encourage the employees, so that they have a high motivation to perform their duties. The importance role of motivation to encourage employee morale in completing the work is very needed (Hasibuan, 2009). Every human in carrying out his/her activities is essentially driven by the motivation. Work motivation is a condition and energy that drives self-directed or directed employees to achieve organizational goals of the company (Mangkunegara, 2005).

There are many motivation theories that affect the way of organizations in managing the employees to achieve a motivated workforce. The theory explains why people behave as they do. The factors and strategies of recommendation can get the best out of employees in terms of their commitment in working. The complexity of the problem is the consideration in motivating workers to work more effectively, and it is always not an easy task. (Dartey-Baah \& Amoako, 2011).

Aworemi, Abdul-Azeez, \& Durowoju (2011) reported that the use of Vroom's theory of motivation in an empirical study of employee motivation factors in Nigeria. Victor H. Vroom (as cited in Aworemi, Abdul-Azeez, \& Durowoju, 2011) defined motivation as a process in organizing the choice among alternative forms of voluntary activity, and it is controlled by individual. Vroom also stated that people will be motivated to pursue their desired goals if: (1) They believe in the value of goals, and (2) They believe that their actions will guarantee to achieve of these goals.

In a more detailed form, Vroom believe that people's motivation to do something will depend on the value of efforts and multiplied with their belief that the effort will actually help them to achieve the goals. This study has confirmed the importance of motivational factors in getting the best from the employees. It has revealed through the ranking at which order all these factors motivate the employees. It also provides useful information for the managers and employees. (Aworemi, AbdulAzeez, \& Durowoju, 2011).

In addition to motivation theory of Vroom, specifically Maslow (in Kaur, 2013) stated that people have five kinds of need and that are activated by hierarchical. The needs aroused in a certain order from lowest to highest and the lowest level must be fulfilled first because the continued process. From the point of view of Maslow's theory of motivation, he said that the needs can never be fully met, but the needs are no longer motivate if it is nearly fulfilled.

The current development of organization communication see that the communication as one of the most dominant activity and important in the organization. The relationship grows from the communication, and then the function and survival of the organization are based on an effective relationship between individuals and groups (Harris \& Nelson, 2008). Each individual in the organization is the most important resources because they have to interact and motivate their subordinates and colleagues, communicate with management and customers, and achieve organizational goals (Ali \& Patnaik, 2014:1). Communication has a very vital role for human life, therefore we must give careful attention to communication (Morissan, 2013).

Motivation becomes important in an organization because motivation may encourage employees to achieve the organization's goal. Moreover, motivation in the form of encouragement includes things like generating, directing, and keeping behavior towards the achievement of goals. If employees feel that management communicates in an efficient manner, it motivates them to perform better and develop team spirit is very important for the smooth functioning of the organization (Rajhans, 2012:81).

There are factors that affect motivation in organizations by Frederick Herzberg (Wibowo, 2007), they are: (1) The real motivators encourage people to get their needs. Motivators include achievement, recognition, interest in work, responsibility and progress, (2) Hygiene factors are basic 
human needs, it not motivation form, but the failure to get it can cause dissatisfaction. Hygiene factors include salaries and benefits, working conditions, organizational policy, position status, job security, supervision and autonomy, life in the workplace and personal life.

Interpersonal communication is the communication between people who are usually conducted face-to-face in personal or non-personal situation (Morissan, 2013: 14). People in an organization usually have experience of communication with number of ways. Communication messages move vertically between levels of hierarchy and move horizontally to other people who have the same level (De Nobile, 2008).

According to Elena Buja (2009), nonverbal communication has an influence on motivation. Based on her research, nonverbal communication is an essential thing. Nonverbal communication can help employees in understanding the information and establish a sense of comfort in working. In addition, the work environment also gives impact on work motivation. If the employee motivation is good, then the purpose of an organization will be achieved. On the contrary, if the nonverbal communication in a company or organization is not good, it will affect motivation and performance of employees. Beside that, it can create disharmony among employees. Nonverbal communication is always found in daily communication in an organization.

DeVito (2012) argued that there are eight channels of nonverbal communication, they are body communication, facial communication, eye communication, touch communication, paralanguage, spatial messages and territoriality communication, artifactual communication), and temporal communication. They all have an important role in interpersonal communication.

Velez and Cano (2012) explained that there is a relationship between verbal immediacy and nonverbal immediacy on motivation. Based on these studies, it is known that nonverbal communication quite influential in mediation function to form motivation in doing something. According to Richmond, Gorham, and McCroskey (as cited in Velez \& Cano, 2012), the proximity of nonverbal communication focuses on the behaviors such as eye contact, posture, gestures, physical proximity and personal touch. It is an impact on building self-efficacy or effectiveness in doing something.

Beside nonverbal communication, direct interpersonal interaction with fellow employees and leaders has also a big role in shaping the work motivation. The survival of an organization lies in the ability and effectiveness of leaders in communicating effectively and motivating employees to achieve corporate objectives (Buble, Juras, \& Matic, 2014). Effective interpersonal communication by leaders in a company can improve company's commitment and become motivation of employees (Sunyoto, 2013).

Competence of leaders in good interpersonal communication can make employees motivated to develop the tasks that assigned to them. It makes the employee wants to increase his/her ability in the form of expertise and skills, energy and time to carry out the tasks which is his/her responsibility and to fulfill his/her obligations in order to achieve company goals (Siagian, 2012:138).

Siburian (2013) found that with effective interpersonal communication, organizational culture, job satisfaction, and high achievement motivation, the interpersonal communication of high school teacher in Humbang Hasundutan become higher. It shows that for optimizing the commitment, it needs to improve the effectiveness of interpersonal communication, organizational culture, job satisfaction, and achievement motivation (Siburian, 2013). Similar results of the research that relating to the influence of interpersonal communication and motivation leaders also expressed by Erni Murniati (2012). She explained that there is a positive relationship and slightly strong between university leader and motivation of teachers in Universitas Setia Bhakti (Murniarti, 2012). 
Goris (2007:747) stated, "Upward communication on the organization gives more fundamental dilemma for employees. Although the best interests of the organization often presented, when employees express all they know about the problems and opportunities, but to disclose such information can make employees lose jobs and careers inhibition in work". According to Grunig (as cited in Chen, 2008), the key in creating and maintaining good and harmonious relations between employees and the management in the process of high-quality communication is more directed to symmetric communication than asymmetric communication.

Internal communication includes communication climate which consists of several factors, such as trust, joint decision-making, honesty, openness in downward communication, listening to upward communication, and focus on high performance goals (Pace \& Faules, 2010). Watkin and Hubbard (as cited in Ghanbari \& Eskandari, 2013) stated that a high performing organization has a climate with certain measurable characteristics. Based on this research, it is known that how an organizational climate can directly explain the success of the emoploye's work performance of the organization's environment up to $30 \%$.

Research on organizational climate is an analysis at the individual level which concentrating on what is called psychological work climate. In this approach, the individual co-workers were asked to indicate the climate in their workplace (Tordera, G. R., \& Peiro', 2008). Meilita (2014) revealed the results of studies showing that organization communication climate is included in the quite good category and has a positive and significant effect on work motivation.

Based on the background that has been explained, the purpose of this research is to reveal how the role of the communication that occurs in the organization on employee motivation. The research problem to be examined is about the relationship of employee motivation on several communication factors, such as nonverbal communication, interpersonal communication of leader, and communication climate. The research questions in this study are: (1) How is the role of nonverbal communication on employee motivation in the workplace? (2) How is the role of interpersonal communication of leader on employee motivation in the workplace? (3) How is the role of the climate communication on employee motivation in the workplace?

\section{METHODS}

The method used in this research is descriptive qualitative method. Qualitative research is a research uses inductive thinking, which focuses on the specific things (empirical facts) to the general things (frameworks). According Kriyantono (2009), the type of descriptive research makes systematic description, factual and accurate information about the facts and the properties of a particular object.

According to Bogdan and Tylor (as cited in Moleong, 2008), qualitative research is a research procedure that produces descriptive data in the written or spoken form about people and behaviors that can be observed. Methods of data collection of this study are literature study. Literature study is the first step of data collection, which is directed to the search of data and information through documents or research journals in the form of written documents, photographs, images, or electronic documents that can support the writing process. The results of research will be more credible if it is supported with photographs, academic papers and art that are available (Sugiyono, 2013).

Data collection techniques used in this research is literature study with observation method. This method can be divided into several techniques, and among them is note technique. Note technique is a technique of data collection by using books, literature, or library materials, then record or citing expert opinion that can reinforce the basic theory in the research. Observation method with 
note technique is using books, literature, journal / research, and other material relevant to the research. It can usually be found in the library or in a place where writer did the research.

Based on five researchs' result above, this research wants to describe the role of nonverbal communication, interpersonal communication leadership, and communication climate on employee motivation in the workplace. This study describes the relationship between the results with theoretical or basic concepts regarding the role of nonverbal communication, interpersonal communication of leadership and communication climate on employee motivation in the workplace.

Table 1 Research Data of Literature Study

\begin{tabular}{lll}
\hline \multicolumn{1}{c}{ Non Verbal } & \multicolumn{1}{c}{ Interpersonal Communication } & \multicolumn{1}{c}{ Communication Climate } \\
\hline $\begin{array}{l}\text { Nonverbal Communication } \\
\text { On Employee Motivation at }\end{array}$ & Leader Interpersonal Communication & \\
Indian Embassy in Jakarta & Aneka Warna Indah & \\
(Shandyta Ichdinasari, 2014) & (Lisa Febriani, 2014) & $\begin{array}{l}\text { Influence of Communication Climate } \\
\text { on Employee Motivation PT Radio }\end{array}$ \\
$\begin{array}{l}\text { Nonverbal Communication } \\
\text { on Employee Motivation in }\end{array}$ & Vertical Internal Communication on & $\begin{array}{l}\text { Rahmat Emmanuel Ministries } \\
\text { PT Maju Bertiga Indonesia }\end{array}$ \\
$\begin{array}{l}\text { Club in Pondok Indah Outlet } \\
\text { (Kevin, 2014) }\end{array}$ & (Noni, 2014) & \\
\hline
\end{tabular}

\section{RESULTS AND DISCUSSIONS}

Based on the research conducted by Kevin (2014) in PT Maju Bertiga Indonesia, index analysis of respondents' answers on nonverbal communication has been working effectively with the acquisition total value of the average index is $79 \%$. Indicator of questions that have the highest value is how to speak or voice intonation and appearance of friend and boss at work. Then the index based on the analysis of respondents' answers on employee motivation at PT Maju Bertiga Indonesia has already high with the acquisition of the total value of the average index of $80 \%$. Question indicators that have the highest value are award achievement that adds work motivation.

According to correlation coefficients analysis, it can be seen that the variable of nonverbal communication and work motivation have slightly strong relationship with the acquisition of a correlation value, 0.658 . It can be concluded that nonverbal communication and employee motivation variables have a significant relationship. It means if nonverbal communication increases, employee motivation will also increase. Vice versa, if the nonverbal communication decreased then employee motivation will also decrease. Based on the coefficient of determination, it can be seen that the influence of nonverbal communication on employee motivation is $43 \%$ and the rest is $57 \%$ which is the other variables that were not examined in this study.

Shandyta Ichdinasari (2014), an employee at Indian Embassy in Jakarta, also states the same results, nonverbal communication has represented an effective communication with the total value of the average index is $80 \%$. Question indicator that has the highest value is based on facial expression, eye contact, and the appearance of friend and boss at work. The index is based on the analysis of respondents' answers are already high, employee motivation with the total value of the average index by $73 \%$. Questions indicator that has the highest value is about opinions to fulfill their daily needs.

Based on the test results, there is a significant relationship between the variables of nonverbal communication on work motivation. There is a significant influence between the variables of 
nonverbal communication on employee motivation at Indian Embassy Jakarta. Result of 0.603 explains that there is a strong relationship between nonverbal communications on employee work motivation at Indian Embassy Jakarta. There is a strong correlation in the interval 0.60 to 0.799 . Thus, it can be stated that between nonverbal communication and employee work motivation at Indian Embassy Jakarta has a positive relationship.

Based on the research that has been done by Kevin (2014) and Ichdinasari (2014), revealed that nonverbal communication provides a very positive and strong influencein in motivating employees in the workplace. These findings reinforce Buja's findings (2009). It states that the nonverbal communication has influence on motivation. Based on this research, it is concluded that nonverbal communication is an essential thing. Nonverbal communication can help employees to understand the information, form a sense of comfort at work and the environment, which will have an impact on work motivation. The results of these studies also describe that nonverbal communication such as body communication, facial communication, eye communication (DeVito, 2012) becomes the most influential interaction channel occurring in the workplace and also affects the motivation of the employees.

Based on those results, having differences in revealing the dimensions of employee motivation. According to Frederick Herzberg (as cited in Wibowo, 2007), there are two factors that affect motivation in organizations which are motivators factor and hygiene factor. Research by Kevin (2014) on nonverbal communication and employee motivation at PT Maju Bertiga Indonesia, the dominant motivation dimension is the motivator factor. Motivator factor is about achievement and recognition in the workplace. Meanwhile, according to research conducted by Ichdinasari (2014) at the Indian Embassy Jakarta, the dominant motivation dimension is the hygiene factor. Hygiene factor is becoming basic needs or physiological factors for each person to motivate employee performance.

From the analysis of the correlation coefficient, it can be seen that the variables of interpersonal communication and work motivation have a very strong relationship based on the value of the correlation coefficient from Siregar (2013), with the acquisition of a correlation value is 0.807 . Thus, it can be concluded that interpersonal communication leader and employee motivation has a significant relationship. It means that if the leader of interpersonal communication increases, so the employee motivation will also increase and vice versa. According to coefficient of determination, it can be seen that the influence of leader interpersonal communication on employee motivation is $65.1 \%$ and the remaining amount of $34.9 \%$ is the other factors that are not examined in this study.

Relevant research is also carried out by Noni (2014) on O'Coffee club at Pondok Indah Outlet. The findings of the research data are known that employees' response regarding internal communication vertically has total index value of 80 , which based on index value guideline is in the interval range between 68-84 are high or good. The vertical internal communications that took place at O'Coffee club in Pondok Indah outlet, South Jakarta, is proportional or balanced. It means that the communication between public relation managers and subordinates are occurred two-way symmetrical and balanced, so the message of communication conveyed by the officer is immediately understood by the subordinates. Staff (subordinate) does not have trouble in understanding their superior communication message because the message is in accordance with the staff's knowledge and experience.

It is clearly known that the employee motivation variable of O'Coffee club at Pondok Indah outlet, South Jakarta, has a total acquisition of the index value amounted to 83.5 that are based on index value guideline in interval range between 68-84 are high or good. This can be concluded that employee motivation of O'Coffee Club at Pondok Indah outlet, South Jakarta, is high. It means that employees demonstrate responsibility by completing their job well, able to finish the work that has never been done before, able to complete the job quickly when superiors ordered, and have the initiative without orders given by direct superiors. 
Based on the results of two researches conducted by Febriani (2014) and Noni (2014), it reinforce the results of previous research on positive and strong relationship between school principal leadership and teachers motivation in Setia Bhakti University (Murniarti, 2012). Goris (2007) stated that, "Although for organizational interests, it served the best, when employees revealed all that they know about the problems and opportunities but to disclose such information can make employees lose jobs and propelling their careers in the workplace." Effective interpersonal communication will give and increase employee motivation. This also applies to the type of internal vertical communication or leader to subordinate communication. This is supported by the concept that stated organizational communication satisfaction includes satisfaction information level. So, if the information conveyed by leader is clear and precise, then the satisfaction of organizational communication can occur and give an impact on the high motivation (Muhammad, 2014).

Research conducted by Esther (2014) on effect of communication climate in employee motivation showed that the highest index value of 90.7 is an indicator of openness of underward communication in the form of information delivery from leader regarding changes in company policy, listening of upward communication in the form of communication between leader and all employees are running smoothly. Both of these are highly desired by employees related to the communication climate in the company. Based on these results, it can be concluded that the communication climate in PT Radio Rahmat Emmanuel Ministries has been going well.

As for the index, value on employee motivation has the highest value is 90.7. It is an indicator of salaries and benefits needed by the employee from the company, indicator of organization policy that implemented in the organization, indicators of life in the workplace that give comfort vibes because the colleagues are ready to help when others need help, indicator of personal life like family problems has no effect in working. Those four indicators are desirable things for employees' work motivation in the company.

That research is also conducted several test in order to determine the relationship among variables. There is correlation coefficient which stated between two variables have a very strong relationship as seen from the correlation value of 0.941 , which is in between 0.80 to 0,100 . Based on the results of determination coefficient, it was stated that the communication climate affects employee motivation in PT Radio Rahmat Emmanuel Ministries amounted of $88.5 \%$. Then based on simple regression analysis of research showed if every change of communication climate increases one unit, it will increase employee motivation of PT Radio Rahmat Emmanuel Ministries of 1,517 units. Thus, it is evidence that there is a positive influence of climate communication on employee motivation in PT Radio Rahmat Emmanuel Ministries.

Climate communication consists of several factors, such as trust, joint decision-making, honesty, openness in downward communication, listening in upward communication and focus on goals of high performance (Pace \& Faules, 2010: 159). One of the roles of climate communications is trust. The trust in the company is giving the task to the creative team to process the material of raw data and processed it into advertising form with interesting sound effects. When a company gives trust to the creative team to carry out the duties, the creative team must give results that shows achievement as an indicator of work motivation. Watkin and Hubbard (as cited in Ghanbari \& Eskandari, 2013) stated that a high performing organization has a climate with certain measurable characteristics. Based on this research, it is known that how an organizational climate can directly explain for up to $30 \%$ of relative success of employee performance from organization environment. The motivation that generated is dominating in hygene factor. 


\section{CONCLUSIONS}

Based on the analysis and discussion of the roles of nonverbal communication, interpersonal communication of leader, and communication climate on employee motivation can be concluded that nonverbal communication has a significant and positive role in shaping employee motivation. The role includes the management of body communication, facial communication and eye communication. This becomes an important topic in managing nonverbal communication interactions that occur in the organization. Appropriate and positive nonverbal communication will present good employee motivation.

Then interpersonal communication of leader has a very positive role in shaping employee motivation. Satisfaction and effectiveness of organizational communication at the level of satisfaction of the information presented by the leader is clear and precise. Beside that, the satisfaction of organizational communication can occur and have an impact on high employee motivation. The high employee motivation that based on workplace safety in the company is the physiological motivating factor.

Climate communication has a significant role in shaping the employee motivation. Climate communications is one of the trust roles. Management and openness in downward communication is in the form of information delivery from the leader regarding changes in company policy, listening on upward communication is in the form of communication between leader and employees that are running smoothly.

For further research, it is recommended to examine more deeply and more broadly with other communication variables. Several variables related communications, such as variable of verbal communication, horizontal internal communication, organizational culture and other, in order to do further research to discuss the influence of communication on employee motivation.

\section{REFERENCES}

Ali, A., \& Patnaik, B. (2014). Influence of Organizational Climate and Organizational Culture on Managerial Effectiveness: An Inquisitive Study. The Carrington Rand Journal of Social Sciences, 1(2), 001-020.

Aworemi, J. R., Abdul-Azeez, I. A., \& Durowoju, S. T. (2011). An Empirical Study of the Motivational Factors of Employees in Nigeria. International Journal of Economics and Finance Vol. 3, No. 5, October 2011, 227-233.

Buble, M., Juras, A., \& Matić, I. (2014). The Relationship Between Managers' Leadership Styles and Motivation. Journal of Contemporary Management Issues, Vol. 19 No.1, 161-193.

Buja, E. (2009). The Influence of a Teacher's Nonverbal Behavior on Students' Motivation. Bulletin of the Transilvania University of Brasof, 2(51).

Chen, N. (2008). Internal/Employee Communication and Organizational Effectiveness: a study of Chinese corporations in transition. Journal of Contemporary China, 17(54), 167-189.

Cristina, E. (2014). Pengaruh Iklim Komunikasi Terhadap Motivasi Kerja Karyawan PT Radio Rahmat Emmanuel Ministries. Jakarta: Binus University. 
Creswell, J. W. (2013). Research Design: Qualitative, Quantitative, and Mixed Methods Approaches, $4^{\text {th }}$ Edition. Los Angeles, USA: SAGE.

Dartey-Baah, K., \& Amoako, G. K. (2011). Application of Frederick Herzberg's Two-Factor theory in assessing and understanding employee motivation at work: a Ghanaian Perspective. European Journal of Business and Management Vol 3, No.9, 2011, 1-8.

De Nobile, J. J., \& John, M. (2008). Organizational Communication and Job Satisfaction in Australian Catholic Primary Schools. Journal Administration \& Leadership Educational Management, 36(1), 101-122.

DeVito, J. A. (2012). The Interpersonal Communication Book $13^{\text {th }}$ Edition. United States of America: Pearson Education, Inc.

Febriani, L. (2014). Komunikasi Interpersona Pemimpin Terhadap Motivasi Kerja Karyawan Pada PT Aneka Warna Indah. Jakarta: Binus University

Ghanbari, S., \& Eskandari, A. (2013). Organizational Climate, Job Motivation and Organizational Citizenship Behavior. International Journal of Management Perspective, Vol. 1. No. 3, 1-14.

Goris, J. R. (2007). Effects of satisfaction with communication on the relationship between individualjob congruence and job performance/satisfaction. Journal of Management Development, 26(8), $737-752$.

Harris, T. E., \& Nelson, M. D. (2008). Applied organizational communication: Theory and practice in a global environment. New York: Lawrence Erlbaum.

Hasibuan, M. (2009). Organisasi dan Motivasi: Dasar Pemikiran Produktifitas. Jakarta: Bumi Aksara.

Ichdinasari, S. (2014). Komunikasi Nonverbal Terhadap Motivasi Kerja Pegawai Kedutaan Besar India di Jakarta. Jakarta: Binus University.

Kaur, A. (2013). Maslow's Need Hierarchy Theory: Applications and Criticisms. Global Journal of Management and Business Studies. Volume 3, Number 10(2013), 1061-1064

Kevin. (2014). Komunikasi Nonverbal Terhadap Motivasi Kerja Karyawan PT Maju Bertiga Indonesia. Jakarta: Binus University

Kriyantono, R. (2009). Teknik Praktis Riset Komunikasi. Jakarta: Kencana

Murniarti, E. (2012). Hubungan Kepemimpinan Kepala Sekolah dan Kedisiplinan terhadap Motivasi Kerja Guru di Perguruan Setia Bhakti Tangerang. Jurnal Manajemen, 1, 31-48.

Mangkunegara, A. P. (2005). Sumber Daya Manusia Perusahaan. Bandung: Remaja Rosdakarya

Meilita, M. (2014). Pengaruh Iklim Komunikasi Organisasi dan Kepuasan Kerja Karyawan Terhadap Motivasi Kerja Karyawan (Studi Kasus Pada Karyawan Bagian Transaksi Energi PT. PLN (Persero) Wilayah Kalimantan Barat Area Sanggau). E-journal Universitas Atma Jaya Yogyakarta, 1-14.

Moleong, L. J. (2008). Metodologi Penelitian Kualitatif. Bandung: Remaja Rosdakarya

Morissan. (2013). Teori Komunikasi Individu Hingga Massa. Jakarta: Kencana Prenada Media Group. 
Muhammad, A. (2014). Komunikasi Organisasi (ed. 13 ${ }^{\text {th }}$ ). Jakarta: Bumi Aksara.

Noni. (2014). Komunikasi Internal Vertikal Dengan Kinerja Karyawan O'COFFEE CLUB Outlet Pondok Indah, Jakarta. Jakarta: Binus University

Pace, R. W., \& Faules, D. F. (2010). Komunikasi Organisasi Strategi Meningkatkan Kinerja Perusahaan (7 ed.). In D. Mulyana, (Ed.), \& D. Mulyana, (Trans). Bandung: PT Remaja Rosdakarya.

Rajhans, K. (2012). Effective Organizational Communication: a Key to Employee Motivation and Performance. Interscience Management Review (IMR), 2 (2), 81-85. ISSN: 2231-1513.

Siagian, Sondang P. (2012). Teori Motivasi dan Aplikasinya. Jakarta: Rineka Cipta.

Siburian, T. A. (2013). The Effect of Interpersonal Communication, Organizational Culture, Job Satisfaction, and Achievement Motivation to Organizational Commitment of State High School Teacher in the District Humbang Hasundutan, North Sumatera, Indonesia. International Journal of Humanities and Social Science, 3(12), 247-264.

Siregar, S. (2013). Metode Penelitian Kuantitatif: Dilengkapi Perbandingan Perhitungan Manual \& SPSS. Jakarta: Kencana Prenada Media Group.

Sugiyono. (2013). Metode Penelitian Kuantitatif Kualitatif dan $R \& D$ (ed. 19 $9^{\text {th }}$ ). Bandung: ALFABETA.

Sunyoto, Danang. (2013). Teori, Kuesioner, dan Proses Analisis Data Perilaku Organisasional. Yogyakarta: CAPS

Tordera, N., V., G.-R., \& Peiro', J. M. (2008). The moderator effect of psychological climate on the relationship between leader-member exchange (LMX) quality and role overload. European Journal of Work and Organizational Psychology, 17, 55-72.

Tripathi, P. C., \& Reddy, P. N. (2012). Principles of Management. New Delhi: The McGram-Hill Company.

Velez, Jonathan J. (2012). Instructor Verbal and Nonverbal Immediacy and the Relationship with Student Self-efficacy and Task Value Motivation. Journal of Agricultural Education, 53(2).

Wibowo. (2013). Manajemen Kinerja (Vol. 3). Jakarta: PT Raja Grafindo Persada 